\begin{tabular}{|c|c|c|}
\hline$W_{\text {INESEG }}$ & $\begin{array}{l}\text { INTERNATIONAL } \\
\text { ENGINEERING, } \\
\text { SCIENCE AND } \\
\text { EDUCATION } \\
\text { GROUP }\end{array}$ & $\begin{array}{l}\text { Middle East Journal of Science } \\
\text { (2017) 3(1):32-50 } \\
\text { Published online August 28, } 2017 \text { (http://dergipark.gov.tr/mejs) } \\
\text { doi: 10.23884/mejs.2017.3.1.05 } \\
\text { ISSN:2536-5312 } \\
\text { Received: May 24, } 2017 \quad \text { Accepted: August } 01,2017\end{array}$ \\
\hline
\end{tabular}

\title{
THE RESEARCH WEED SPECIES, DENSITY AND FREQUENCY IN PARK AND GARDEN OF ADANA METROPOLITAN MUNICIPALITY AND DISTRICT
}

\section{Tamer $\ddot{U} S T \ddot{U N E R}{ }^{*}$}

\author{
${ }^{* 1}$ University of Kahramanmaras Sütcü İmam, Faculty of Agriculture, \\ Department of Plant Protection, Kahramanmaras, Turkey \\ *tamerustuner@ksu.edu.tr
}

\begin{abstract}
Ornamental plants which are grown as house plants, landscaping plants or for horticultural purposes mostly because of the leaves and the flowers that attract people. The improtance of ornamental plants increased in our urban life today. Because people may expreince a great socialepression due to the fact that they become exposed to many negative factors in the social life of a metropolitan city. By taking this aspect into the account, in the developing understanding of the modern city, mayors and city planners are now planning more livable cities with an increased amount of green fields. For this purpose, we have to allocate more space to the ornamental and landscape plants. However, a number of problems is faced in the cultivation of ornamental plants. In particular, weeds, diseases and pests are important topics in the cultivation of ornamental plants. If we do not fight against the weeds, diseases and pests, we would be unsuccessful in growing ornamental plants. A highly significant amount of damage caused by weeds is concerned in the cultivation of ornamental plants. Especially considering the fact that weeds can consume 3-4 times more water, organic and inorganic nutrients compared to ornamental plants. of 104 species of weeds detected in Adana Region, 1 of them was Pterydophyta, 19 were Monocotyledons, and 84 were Dicotyledon. An avarage of 116.139 number of weeds per metersquare were detected in the region. The highest density (165.390 number/m2) of weed species was found in Adana Metropolitan Municipality center, followed by Cukurova (114.159), Seyhan (113.030), Yüregir (106.164), Kozan (99.896) and Ceyhan (98.199) districts, respectively. The narrow leaved weeds which were found to be in the highest density (weed average $>10$ ) in ornamental plants growing areas of Adana region; Cynodon dactylon, Agropyron repens, Setaria viridis, Digitaria sanguinalis. Broad leaf weeds; Taraxacum officinale and Portulaca oleracea..
\end{abstract}

Key words: Ornamental plants, family, weed species and density

\section{Introduction}

Ornamental plants which are grown as house plants, landscaping plants or for horticultural purposes mostly because of the leaves and the flowers that attract people. Ornamental plant sector has 
an important place in plant production. It is considered as an effective sector that adds values to the economy and provides a great employment. Ornamental plants are produced in more than 50 countries around the globe. Turkey, with its diverse ecological and soil properties, has the potential to become a significant production center for ornamentals. It has been estimated that Turkey's ornamental producing capacity reaches up to 600 million dollars, of which 100 to 150 million dollars are obtained through imports. Ornamental plants are a good alternative in Turkey's agriculture thanks to the country's rich climate, soil, water and microclimatic properties [1]. For exterior space, Adana region is a place where almost all phanerogams, crytogams and fruits can be grown along with some Mediterranean plant varieties at international strandards.

In today's urban life, the importance of ornamental plants increased because people may experience a great social (mental) depression due to the fact that they become exposed to many negative factors (air pollution, noise pollution, work-related stress) in the social life of a metropolitan city. For the solution of sociological and psychological problems resulted from these kinds of problems, the streets, alleys, refuges, intersections and the roadways with landscape designs that calm people's minds by their beautiful and attractive appearances and odors become increasingly important. It has been known that being exposed to the neat and nice appearance of the parks, gardens and plants while starting the day in the morning has a positive impact on peoples psychologies. In the past, gardening and landscaping works in the cities have been largely ignored, but now, considering the recent conditions of the urban life, they began to be taken seriously. Today, stress has been shown to be the reason of many human diseases. Not only do ornamental plants (flowers, trees, shrubs and plants in the form of trees) and grass fields provide the image of the city with an extra beauty, but also the fact that they contribute very positively to human psychology have been continuously expressed by medical experts. By taking this aspect into the account, in the developing understanding of the modern city, mayors and city.

Planners are now planning more livable cities with an increased amount of green fields. We are obliged to provide our people with more beautiful and aesthetic living areas by preparing a 50-year master plan. For this purpose, we have to allocate more space to the ornamental and landscape plants. However, a number of problems is faced in the cultivation of ornamental plants. In particular, weeds, diseases and pests are important topics in the cultivation of ornamental plants. If we do not control against the weeds, diseases and pests, we would be unsuccessful in growing ornamental plants. In the scope of this project, the damages caused by the weeds common among ornamental plants were investigated. A highly significant amount of damage caused by weeds is concerned in the cultivation of ornamental plants. Especially considering the fact that weeds can consume 3-4 times more water, organic and inorganic nutrients compared to ornamental plants. Convolvulus species are especially dangerous not only because they can consume more nutritional elements and water compared to the ornamental but also they grow by clinging to the host's transmission harnesses. Therefore, it causes a great amount of stress on the plant. Agropyron repens participates to plants food and water by taking a higher amount of them from the soil. Besides, Agropyronrepens, Cynodon dactylon, Sorghum halepense and Phragmites australis cause a disadvantageous effect on the ornamental plant by blocking the growth of the plant root and also showing a allelopathic impact. In addition to the direct negative effects of the weeds on the ornamental, they can harm the plant indirectly by playing a role as a secondary host for certain diseases and pests. Some weed species such as Malvaneglecta, Convolvulus spp., Sonchus oleraceus and Sorghum halepense are the intermediate hosts of certain 
fungal pathogens such as Erysiphe spp. and Puccinia spp. Thereby causing them to infect the ornamental plant and to spread. The weed species, Sonchus oleraceus, Sorghum halepense and Phragmites australis are the secondary hosts of Aphis spp., Empoasca spp., which help them infect the ornamentals and cause an epidemic [2]. In the fields he investigated to determined 43 weed species and found that, as the chemical intervention the combination of 2,4-D Amin+Dicamba was effective against Taraxacum officinale, Trifolium spp., Plantago spp. and Medicago sativa [3]. The most common weed species seen in Ankara city center was Trifolium repens, while Taraxacum spp. was detected as the second most common [4]. As a part of the control against the weed, found that Trifolium spp. and Taraxacum spp. were amongst the weed, besides the other weeds such as Plantago spp., Convolvulus arvensis, Agropyron repens and Acroptilon repens could also be observed albeit in small quantities [5,6]. Additionally, they realized Glyphosatei was effective againstthe species found in the areas to be grassed, Agropyron repens, Cynodon dactylon, Acroptilon repens and Taraxacum spp. The weeds detected in the conditions of Central Anatolia were Acroptilon repens (L.) D. C., Agropyron repens L., Amaranthus albusL., Amaranthus viridis L., Chenopodium album L., Convolvulus arvensis L., Malva neglecta L., Portulaca oleracea L. and Tribulus terrestris L. [7]. At the end of the survey conducted in the grass of Sabiha Gokcen Airport, 25 species and 26 genus of weed from 16 different familias were detected. These species were Anagallis arvensis, Chenopodium album, Convolvulus arvensis, Matricaria chamomilla, Plantago lanceolata, Polygonum spp., Trifolium repens, Erigeron canadensis, Medicago sativa and Plantago major [8].

First mowing fastens the plant spread, tillering and becoming more frequent. Mowing should be performed before the plants grow too tall. If moving is performed late, the bottom part of the grass becomes pallid. The time of the first mow depends on the species. However, in general, it is suitable for most grasses to be mowed when they reach 6 to $8 \mathrm{~cm}$ of height. It is usually recommended to leave the $2 / 3$ of the grass un-mowed, i.e. mowing the grass at 4 to $5 \mathrm{~cm}$ from ground. Deep mowing causes the vegetation cover to lose its frequency. In light soils, rubbing before the first mow helps the plants remain attached to the ground. Sometimes, rubbing again after the mow gives a strengthening impact on the contact of plant roots with the soil. However, rubbing should be performed when the soil is dry. Rubbing might cause problem on wet and heavy soils [9]. It is rather expensive to constitute the lawns. Therefore, these areas need to be protected and the control against weeds are crucial for them to be long lasting. When left disturbed, weeds cause the grass to weaken by using their nutrition and water sources. Some weed species make the lawn disappear by dominating the area. They may ruin the appearance and increase the expense of maintenance. Although many species of weed may be present in the lawns, especially the biennial and perennial ones in the form of rosettes cause the biggest problems. Of these kinds of weeds, the most dangerous species for the lawn are Taraxacum officinale Wigg., Plantago spp., Convolvulus arvensis L., Capsella bursa-pastoris L. and Trifolium spp. [10]. Some of the weeds that are problematic in the growth of tulip, clove and gladiola in Turkey. Amaranthus retroflexus L, Amaranthus viridis L, Cynodon dactylon, Agropyron repens (L.) P.Beauv., Setaria viridis, Taraxacum officinale, Portulaca oleracea L., Digitaria sanguinalis (L.) Scop.,Cyperus rotundus L., Sorghum halepense, Bromus tectorum, Rumex crispus L., Alopecurus myosuroides, Echinochloa crus-galli (L.) P. Beauv., Lactuca serriola L., Solanum nigrum, Malva neglecta, Chenopodium album L., Convolvulus arvensis, Avena sterilis L., Convolvulus sepium, Xanthium strumarium L. and Oxalis corniculata [11]. The species used for the constitution of lawns; Festuca 
rubra, Zoysia spp., Poa pratensis, Festuca arundinacae, Cynadon dactylon, Agrostis tenius and Lolium perene [12].

\section{Methods}

\subsection{Used methods}

The survey study was conducted in Adana region's (Adana Metropolitan Municipality, Aladag, Ceyhan, Cukurova, Feke, İmamoglu, Karaisalı, Karatas, Kozan, Pozant1, Saimbeyli, Sarıcam, Seyhan, Tufanbeyli, Yumurtalık and Yüregir) ornamental plants area in 2016. The region was divided 16 regions by considering region's ornamental plants area ranges and in a certain amount of examples from each region was taken as represent aforesaid region. It was considered that distance of studied orchards is at least $3 \mathrm{~km}$ and removing side affects by starting $15 \mathrm{~m}$ inside of the orchard side. In the survey study, a census was took by drawing a frame for $1 \mathrm{~m}^{2} 4$ times in 1 decare area [13]. Number of weeds in $\mathrm{m}^{2}$ was calculated by going into total number of all species in $1 \mathrm{~m}^{2}$ area to total studied area. In the survey area, large leafed weeds were considered as plant, lanceolate leafed weeds were considered by counting stems and written on questionnaries. Species, numbers and coverage of weeds were written down and frequency of occurrence, number of plant and general coverage of obtained datas were calculated by using the following formulas [14]. Weed density was calculated via Density $=\mathrm{B} / \mathrm{n}$ formula [15]. In the formula; $\mathrm{B}=$ Total weeds number in the taken example, $\mathrm{n}=$ Number of taken example. Frequency of occurrence (F.O.); the value that shows that a weed's seen rate inside how percent of studied farms about this weed, and calculated with following formula. Frequency of occurrence $(\%)=\mathrm{n} / \mathrm{mx} 100, \mathrm{n}$ : Number of farms where one species is in, $\mathrm{m}$ : Total number of farm that measured. Species Coverage (T.K.A.): It is expressed as average value that any species of weed covered surface. G.K.A $(\%)=$ T.K.A./m. G.K.A.: General coverage, m: Total number of exemplifications. Determined to Turkish names weeds the benefiting from [16] and [17] is stated in the results section.

It can not be diagnosed during a survey made herbarium samples taken weeds after in Faculty of Agriculture, Department of Plant Protection in KSU was diagnosed in Herbology laboratory. In the identification of weed species usually can not be diagnosed which was identified using in the field as a source of water weeds "Water Weeds" [18] and "Flora of Turkey" book [19].

As suggested by Ustuner and Güncan [20], density scale was used as follows;

Density scale,
A. High dense (The average plant more than 10)
B. Dense (The average plant 1-10 between)
C. Mid dense (The average plant 0.1-1)
D. Low dense (The average plant 0.01 to 0.1 )
E. Scarce (The average plant less than 0.01)

The survey study was conducted in accordance with stated place and frame number in Table 1 in Adana regions.

Table1.Studied Regions, Ornamental Plants Areas are and Number of Drawn Frame in Adana Region 


\begin{tabular}{|c|c|c|}
\hline Regions & $\begin{array}{l}\text { Ornamental Plants area } \\
\text { (da) }\end{array}$ & $\begin{array}{l}\text { The Number of Frames } \\
\text { Discarded (number) }\end{array}$ \\
\hline Adana & 93 & 32 \\
\hline Aladag & 0 & - \\
\hline Ceyhan & 3 & 9 \\
\hline Cukurova & 4 & 12 \\
\hline Feke & 0 & - \\
\hline İmamoglu & 0 & - \\
\hline Karaisalı & 0 & - \\
\hline Karatas & 0 & - \\
\hline Kozan & 4 & 12 \\
\hline Pozant1 & 0 & - \\
\hline Saimbeyli & 0 & - \\
\hline Sarıcam & 0 & - \\
\hline Seyhan & 5 & 15 \\
\hline Tufanbeyli & 0 & - \\
\hline Yumurtalik & 0 & - \\
\hline Yüregir & 4 & - \\
\hline Total & 113 & 80 \\
\hline
\end{tabular}

\subsection{Materials used in the study}

These materials are garden plants (ornamentals) and weeds. According to this research plan, it was conducted in the municipality of parks and gardens of (Adana Metropolitan Municipality, Aladag, Ceyhan, Cukurova, Feke, İmamoglu, Karaisal1, Karatas, Kozan, Pozant1, Saimbeyli, Sarıcam, Seyhan, Tufanbeyli, Yumurtalık and Yüregir).

\subsection{Geographical features of the research area}

Adana province south of the Mediterranean, while the north west Nigde and Kayseri, Mersin province, north-east of Kahramanmaras, Osmaniye is located to the east and south east of the province of Hatay. Adana, located south of the Anatolian peninsula and the Mediterranean coast is situated between $34^{\circ} 48-36^{\circ} 41$ east longitude and $36^{\circ} 30-38^{\circ} 25$ north latitude. The Mediterranean climate prevails in the region, winters are mild and rainy, summers are hot and dry.

\section{Results And Findings}

At the result of survey, The weed species were detected 104 different species that belonging to 32 family in the park and gardens in Adana region. These weeds were belonged to 1 pterophyta (Pterydophyta), 21 monocots (monokotiledon) and 82 dicots (dikotiledon). The weed density was determined approximate 116.139 (piece $/ \mathrm{m}^{2}$ ) per square meter in Adana region. In this region, different 32 family were detected (Table 2). Tehese; Equisetaceae, Amaryllidaceae, Cyperaceae, Gramineae (Poaceae), Amaranthaceae, Apiaceae (Umbelliferae), Boraginaceae, Caryophyllaceae, Chenopodiaceae, Compositae (Asteraceae), Convolvulaceae, Cruciferae (Brassicaceae), Cuscutaceae, Euphorbiaceae, Fabaceae (Leguminosae), Geraniaceae, Hypericaceae (Guttiferae), Labiatae (Lamiaceae), Malvaceae, Oxalidaceae, Papaveraceae, Plantaginaceae, Polygonaceae, Portulacaceae, 
Primulaceae, Ranunculaceae, Rosaceae, Rubiaceae, Scrophulariaceae (Scrophyllaceae), Solanaceae, Urticaceae and Zygophyhllaceae, respectively.

The weed density was detected the highest dense $165.390\left(\right.$ piece $\left./ \mathrm{m}^{2}\right)$ per square meter for Adana Metropolitan Municipality in the center and this was followed by Cukurova $114.159\left(\mathrm{piece} / \mathrm{m}^{2}\right)$, Seyhan $113.030\left(\right.$ piece $\left./ \mathrm{m}^{2}\right)$, Yüregir $106.164\left(\right.$ piece $\left./ \mathrm{m}^{2}\right)$, Kozan $99.896\left(\right.$ piece $\left./ \mathrm{m}^{2}\right)$ and Ceyhan 98.199 $\left(\right.$ piece $\left./ \mathrm{m}^{2}\right)$ respectively.

In Adana region's in park and garden plants average that density of weeds were found per meter square; The weed was detected high dense that Agropyron repens (L.) P. Beauv.(11.758 piece plant $/ \mathrm{m}^{2}$ ), Cynodon dactylon (L.) Pers.( 10.805), Setaria viridis (L.) P. Beauv. (10.524), Digiteria sangunialis (L.) Scop. (10.211), Taraxacum officinale F.H.Wigg.and (10.090) (avarege weed in $\mathrm{m}^{2}>10$ ); It was found dense Portulaca oleracea L. (9.081), Cyperus rotundus L.(7.086), Sorghum halepense (L.) Pers. (6.609), Rumex crispus L. (5.597), Bromus tectorum L. (5.535), Alopecurus myosuroides Huds. (5.157), Echinochloa crus-galli (L.) P. Beauv. (2.693), Malva neglecta (2.294), ), Amaranthus retroflexus L (1.801), Solanum nigrum (1.749), Chenopodium album L (1.657),Avena sterilis L.(1.548 (average weed in $\left.\mathrm{m}^{2} 1-10\right)$ in ornamental plants field.

Frequency of occurrence for weeds in the region; While A. repens (L.) P. Beauv., C. dactylon (L.) Pers.,D. sanguinalis (L) Scop., S. viridis and S. halepenseare seen more than 50\% in 6 district and C. rotundus $\mathrm{L}$. is seen more than $50 \%$ one district.

In terms of coverage, the rate in the weeds species occurance, A. repens (L.) P. Beauv., C. dactylon (L.) Pers.,D. sanguinalis (L) Scop., S. viridis, S. halepense and C. rotundus L. were determined to be within a range of $25-35 \%$ while below $25 \%$ other species in the study.

Table 2. The Number Of Species And Family Were Problem Weeds İn Grown Of Ornamental Plants According To Districts

\begin{tabular}{|l|c|c|}
\hline Regions & Family number & Species number \\
\hline Adana & 32 & 104 \\
\hline Ceyhan & 23 & 72 \\
\hline Cukurova & 19 & 60 \\
\hline Kozan & 22 & 61 \\
\hline Seyhan & 25 & 65 \\
\hline Yüregir & 25 & 65 \\
\hline
\end{tabular}

Survey results was evaluated separately that was did in Adana region 6 district. These are;

In Adana Metropolitan Municipality, 104 different weeds from 32 families that can be recognised were seen of ornamental plants grown areas. In this region, It was determined high dense 12.691 (piece plant $/ \mathrm{m}^{2}$ ) Cynodon dactylon, 11.826 Agropyron repens, 11.583 Setaria viridis, 11.205 Taraxacum officinale, 11.084 Portulaca oleracea and 10.654 Digitaria sanguinalis (average weed in $\mathrm{m}^{2}>10$ ); dense 9.871 (piece plant $/ \mathrm{m}^{2}$ ) Cyperus rotundus, 9.482 Sorghum halepense, 7.894 Bromus tectorum, 7.351 Rumex crispus, 6.689 Alopecurus myosuroides, 6.462 Echinochloa crus-galli, 3.568 Lactuca serriola, 3.482 Solanum nigrum, 3.475 Malva neglecta, 3.314 Amaranthus retroflexus, 2.925 Chenopodium album, 2.836 Convolvulus arvensis, 1.352 Avena sterilis, 1.294 Convolvulus sepium and 1.150 Xanthium strumarium (average weed in $\mathrm{m}^{2} 1-10$ ) in Table 3. 
The maximum frequency occurrence for weed species was; $53.8 \%$ for A. repens, $52.7 \%$ for $P$. oleracea, $52.1 \%$ for $C$. dactylon, $51.4 \%$ for $T$. officinale, $50.9 \%$ for $S$. viridis, $50.5 \%$ for $D$. sanguinalis and $50.2 \%$ for $C$. rotundus.

General coverage of weeds were $34.1 \%$ for P. oleracea, $32.3 \%$ for T. officinale, $29.8 \%$ for $A$. repens, $28.2 \%$ for $S$. halepense, $27.9 \%$ for D. sanguinalis, $27.2 \%$ for $C$. dactylon, $26.8 \%$ for $C$. rotundus and $25.6 \%$ for $S$. viridis.

Table 3. Weed Density That Viewed As Significant, Frequency Occurrence (\%) And General Coverage (\%) in Ornamental Plants Grown Areas

\begin{tabular}{|c|c|c|c|}
\hline Weeds species & Density $\left(\mathrm{weed} / \mathrm{m}^{2}\right)$ & Frequency $(\%)$ & Coverage $(\%$ \\
\hline Cynodondactylon & 12.691 & 52.1 & 27.2 \\
\hline Agropyronrepens (L.) P.Beauv. & 11.826 & 53.8 & 29.8 \\
\hline Setariaviridis & 11.583 & 50.9 & 25.6 \\
\hline Taraxacumofficinale & 11.205 & 51.4 & 32.3 \\
\hline PortulacaoleraceaL. & 11.084 & 52.7 & 34.1 \\
\hline Digitariasanguinalis (L) Scop. & 10.654 & 50.5 & 27.9 \\
\hline CyperusrotundusL. & 9.871 & 50.2 & 26.8 \\
\hline Sorghum halepense & 9.482 & 32.5 & 28.2 \\
\hline Bromus tectorum $\mathrm{L}$. & 7.894 & 27.4 & 21.6 \\
\hline RumexcrispusL & 7.351 & 14.2 & 19.3 \\
\hline AlopecurusmyosuroidesHuds. & 6.689 & 13.9 & 12.5 \\
\hline $\begin{array}{lll}\text { Echinochloa crus-galli } & \text { (L.) } \\
\text { P.Beauv. } & & \\
\end{array}$ & 6.462 & 11.2 & 10.8 \\
\hline Lactucaserriola $\mathrm{L}$. & 3.568 & 7.6 & 8.2 \\
\hline Solanumnigrum & 3.482 & 6.8 & 7.1 \\
\hline Malvaneglecta & 3.475 & 6.5 & 7.0 \\
\hline Amaranthusretroflexus $\mathrm{L}$ & 3.314 & 6.2 & 6.8 \\
\hline Chenopodium album L. & 2.925 & 6.1 & 6.4 \\
\hline Convolvulus arvensis L. & 2.836 & 5.8 & 8.3 \\
\hline Avenasterilis L. & 1.352 & 4.7 & 6.9 \\
\hline Convolvulus sepium & 1.294 & 3.9 & 5.1 \\
\hline Xanthium strumariumL. & 1.150 & 2.1 & 5.5 \\
\hline
\end{tabular}

In Ceyhan, 72 different weeds from 23 families that can be recognised were seen of ornamental plants grown areas. In this region, It was determined high dense 12.148 (piece plant $/ \mathrm{m}^{2}$ ) for C. dactylon, 11.246 A. repens, 11.187 P. oleracea, 11.120 S. viridis and 10.094 D. sanguinalis; dense 9.155 (piece plant $/ \mathrm{m}^{2}$ ) for T. officinale, 6.405 for C. rotundus, 5.358 for B. tectorum, 5.106 for S. halepense, 4.160 for A. myosuroides, 3.342 for R. crispus L., 2.147 for L. serriola L., 2.060 for A. sterilis, 2.050 for E. crus-galli, 1.224 for C. album, 1.159 for M. neglecta, 1.100 for A. retroflexus and 1.090 for $X$. strumarium respectively (average weed in $\mathrm{m}^{2} 1-10$ ).

The maximum frequency occurrence for weed species was; $52.4 \%$ for A. repens, $52.2 \%$ for $P$. oleracea, $51.7 \%$ for $C$. dactylon, $51.1 \%$ for $T$. officinale, $50.8 \%$ for $S$. viridis, $50.2 \%$ for $D$. sanguinalis and $40.4 \%$ for $C$. rotundus.

General coverage of weeds were $33.8 \%$ for P. oleracea, $30.3 \%$ for T. officinale, $29.8 \%$ for A. repens, $28.2 \%$ for S. halepense, $27.9 \%$ for D. sanguinalis, $28.2 \%$ for C. dactylon, $26.8 \%$ for C. rotundus and $25.6 \%$ for $S$. viridis respeciteviely. 
In Cukurova, 60 different weeds from 19 families that can be recognised were seen of ornamental plants grown areas. In this region, It was determined high dense 11.547 (piece plant $/ \mathrm{m}^{2}$ ) for T. officinale, 11.260 for A. repens, 11.048 for $C$. dactylon, 10.725 for $S$. viridis, 10.184 for P. oleracea, 10.169 for D. sanguinalis; dense 6.830 for $S$. halepense, 6.154 for $R$. crispus, 5.820 for $C$. rotundus, 5.589 for A. myosuroides, 4.952 for B. tectorum, 3.620 for L. serriola, 2.745 for $M$. neglecta, 2.183 for S. nigrum, 2.100 for A. retroflexus., 2.063 for E. crus-galli, 1.862 for C. album, 1.260 for $A$. sterilis and 1.140 for $X$. strumarium respectively (average weed in $\mathrm{m}^{2} 1-10$ ).

The maximum frequency occurrence for weed species was; $52.8 \%$ for A. repens, $51.8 \%$ for $P$. oleracea, $51.5 \%$ for $C$. dactylon, $50.7 \%$ for $S$. viridis, $50.5 \%$ for $T$. officinale and $50.1 \%$ for $D$. sanguinalis.

General coverage of weeds were $29.7 \%$ for $T$. officinale, $28.6 \%$ for A. repens, $28.4 \%$ for $P$. oleracea, $28.2 \%$ for $S$. halepense, $26.8 \%$ for C. rotundus, $26.2 \%$ for $C$. dactylon, $25.4 \%$ for $D$. sanguinalis and $25.1 \%$ for $S$. viridis.

In Kozan, 61 different weeds from 22 families that can be recognised were seen of ornamental plants grown areas. In this region, It was determined high dense 13.145 (piece plant $/ \mathrm{m}^{2}$ ) for A. repens, 11.218 for $D$. sanguinalis and 11.120 for S. viridis; dense 9.356 for $C$. dactylon, 8.100 for $S$. halepense, 7.405 for C. rotundus, 6.580 for B. tectorum, 5.187 for P. oleracea, 5.159 for T. officinale, 4.346 for $R$. crispus, 4.120 for A. myosuroides, 2.470 for L. serriola, 1.596 for M. neglecta, 1.148 for S. nigrum, 2.000 for A. sterilis, 1.506 for E. crus-galli, 1.310 for C. arvensis and 1.110 for A. retroflexus respecitvely.

The maximum frequency occurrence for weed species was; $51.8 \%$ for A. repens, $51.6 \%$ for $D$. sanguinalis, $50.4 \%$ for $S$. viridis, $50.1 \%$ for $C$. dactylon, $50.0 \%$ for $S$. halepense and $25.3 \%$ for $C$. rotundus.

General coverage of weeds were $32.1 \%$ for A. repens, $31.6 \%$ for $D$. sanguinalis, $29.2 \%$ for $S$. halepense, $28.0 \%$ for $S$. viridis, $26.9 \%$ for $C$. dactylon and $25.8 \%$ for $C$. rotundus.

In Seyhan, 65 different weeds from 25 families that can be recognised were seen of ornamental plants grown areas. In this region, It was determined high dense 12.320 (piece plant $/ \mathrm{m}^{2}$ ) for T. officinale, 11.548 for $C$. dactylon, 10.962 for $D$. sanguinalis, 10.826 for $A$. repens and 10.475 for $S$. viridis; dense 8.780 (piece plant $/ \mathrm{m}^{2}$ ) for C. rotundus. 8.283 for P.oleracea, 7.189 for A. myosuroides, 5.856 for $R$. crispus, 5.830 for S. halepense, 3.895 for B. tectorum, 2.375 for M. neglecta, 2.116 for A. retroflexus, 2.067 for E. crus-galli, 1.786 for C. album, 1.460 for A. sterilis, 1.435 for C. arvensis, 1.243 for $X$. strumarium, 1.185 for S. nigrum and 1.162 for L. serriola respecitvely.

The maximum frequency occurrence for weed species was; $52.7 \%$ for $T$. officinale, $51.6 \%$ for C. dactylon, $51.20 \%$ for $D$. sanguinalis, $50.9 \%$ for A. repens, $50.3 \%$ for $S$. viridis, $36.2 \%$ for $C$. rotundus and $27.5 \%$ for $P$. oleracea.

General coverage of weeds were $35.4 \%$ for $T$. officinale $32.1 \%$ for $C$. dactylon, $30.6 \%$ for $D$. sanguinalis, $29.8 \%$ for A. repens, $29.0 \%$ for $S$. viridis, $25.7 \%$ for $C$. rotundus and $24.6 \%$ for $P$. oleracea respectively.

In Yüreğir, 65 different weeds from 25 families that can be recognised were seen of ornamental plants grown areas. In this region, It was determined high dense 11.248 (piece plant $/ \mathrm{m}^{2}$ ) for A. repens, 11.159 for $T$. officinale, 10.184 for $P$. oleracea, 10.125 for $S$. viridis and 10.042 for $C$. 
dactylon; dense 9.169 for $D$. sanguinalis, 6.534 for $R$. crispus, 4.532 for B. tectorum, 4.310 for $S$. halepense, 4.240 for C. rotundus, 3.240 for L. serriola, 3.196 for A. myosuroides, 2.415 for M. neglecta, 2.384 for $S$. nigrum, 2.014 for E. crus-galli, 1.826 for C. album, 1.543 for C. arvensis, 1.160 for A. sterilis, 1.070 for A. retroflexus and 1.040 for X. strumarium respectively (Table 4).

Table 4. Weed Species, Density and Family According to in Field Survey

\begin{tabular}{|c|c|c|c|c|c|c|c|}
\hline \multirow{2}{*}{\begin{tabular}{|l|}
$\begin{array}{l}\text { Adana Metropolitan } \\
\text { Municipality }\end{array}$ \\
Weedspecies and family
\end{tabular}} & \multicolumn{6}{|l|}{ Regions } & \multirow{2}{*}{$\begin{array}{l}\text { Density(piecepl } \\
\text { ant } / \mathrm{m}^{2} \text { ) }\end{array}$} \\
\hline & $\begin{array}{l}\text { Adana } \\
\text { Metropo } \\
\text { litan } \\
\text { Municip } \\
\text { ality }\end{array}$ & $\begin{array}{l}\text { Ceyh } \\
\text { an }\end{array}$ & $\begin{array}{l}\text { Cukur } \\
\text { ova }\end{array}$ & $\begin{array}{l}\mathrm{Koz} \\
\text { an }\end{array}$ & $\begin{array}{l}\text { Seyh } \\
\text { an }\end{array}$ & Yüregir & \\
\hline \multicolumn{8}{|l|}{ PTERIDOPHYTA } \\
\hline \multicolumn{8}{|l|}{ Familya: Equisetaceae } \\
\hline Equisetum arvense L. & 0,980 & 0 & 0 & 0 & 0,001 & 0 & 0,1635 \\
\hline \multicolumn{8}{|l|}{$\begin{array}{l}\text { MONOCOTYLEDON } \\
\text { EAE }\end{array}$} \\
\hline \multicolumn{8}{|l|}{$\begin{array}{l}\text { Familya:Liliaceae } \\
\text { (Amaryllidaceae) }\end{array}$} \\
\hline Allium rotundum & 0,492 & 0 & 0 & 0 & 0 & 0,018 & 0,085 \\
\hline Allium vineale $\mathrm{L}$. & 0,640 & 0 & 0 & 0 & 0 & 0 & 0,10666 \\
\hline \multicolumn{8}{|l|}{ Familya: Cyperaceae } \\
\hline Cyperus rotundusL. & 9,871 & $\begin{array}{l}6,40 \\
5\end{array}$ & 5,820 & $\begin{array}{l}7,40 \\
5\end{array}$ & 8,780 & 4,240 & 7,08683 \\
\hline \multicolumn{8}{|l|}{$\begin{array}{l}\text { Familya: Gramineae } \\
\text { (Poaceae) }\end{array}$} \\
\hline $\begin{array}{l}\text { Aegilops columnaris } \\
\text { ZHUK. }\end{array}$ & 0,865 & $\begin{array}{l}0,21 \\
4 \\
\end{array}$ & 0,019 & 0 & 0 & 0 & 0,183 \\
\hline $\begin{array}{l}\text { Agropyron repens (L.) } \\
\text { P.Beauv. }\end{array}$ & 11,826 & $\begin{array}{l}12,2 \\
46\end{array}$ & 11,260 & $\begin{array}{l}13,1 \\
45\end{array}$ & $\begin{array}{l}10,82 \\
6\end{array}$ & 11,248 & 11,7585 \\
\hline $\begin{array}{l}\text { Alopecurus } \\
\text { myosuroidesHuds. }\end{array}$ & 6,689 & $\begin{array}{l}4,16 \\
0\end{array}$ & 5,589 & $\begin{array}{l}4,12 \\
0\end{array}$ & 7,189 & 3,196 & 5,15716 \\
\hline Avena sterilis $\mathrm{L}$. & 1,352 & $\begin{array}{l}2,06 \\
0\end{array}$ & 1,260 & $\begin{array}{l}2,00 \\
0\end{array}$ & 1,460 & 1,160 & 1,54866 \\
\hline Bromus arvensisL. & 0,482 & $\begin{array}{l}0,01 \\
7 \\
\end{array}$ & 0,041 & $\begin{array}{l}0,00 \\
3\end{array}$ & 0 & 0 & 0,0905 \\
\hline Bromus tectorum $\mathrm{L}$. & 7,894 & $\begin{array}{l}5,35 \\
8\end{array}$ & 4,952 & $\begin{array}{l}6,58 \\
0\end{array}$ & 3,895 & 4,532 & 5,53516 \\
\hline $\begin{array}{l}\text { Cynodon dactylon (L.) } \\
\text { Pers. }\end{array}$ & 12,691 & $\begin{array}{l}10,1 \\
48 \\
\end{array}$ & 11,048 & $\begin{array}{l}9,35 \\
6 \\
\end{array}$ & $\begin{array}{l}11,54 \\
8 \\
\end{array}$ & 10,042 & 10,8055 \\
\hline Dactylis glomerataL. & 0,859 & $\begin{array}{l}0,25 \\
6\end{array}$ & 0,573 & $\begin{array}{l}0,38 \\
4\end{array}$ & 0,004 & 0,583 & 0,44316 \\
\hline
\end{tabular}




\begin{tabular}{|c|c|c|c|c|c|c|c|}
\hline $\begin{array}{l}\text { Digitaria sanguinalis }(\mathrm{L}) \\
\text { Scop. }\end{array}$ & 10,654 & $\begin{array}{l}9,09 \\
4\end{array}$ & 10,169 & $\begin{array}{l}11,2 \\
18\end{array}$ & $\begin{array}{l}10,96 \\
2\end{array}$ & 9,169 & 10,211 \\
\hline $\begin{array}{l}\text { Echnicola crus-galli (L.) } \\
\text { P.Beauv. }\end{array}$ & 6,462 & $\begin{array}{l}2,05 \\
0\end{array}$ & 2,063 & $\begin{array}{l}1,50 \\
6 \\
\end{array}$ & 2,067 & 2,014 & 2,69366 \\
\hline Hordeum vulgare L. & 0,210 & $\begin{array}{l}0,21 \\
0\end{array}$ & 0,016 & $\begin{array}{l}0,02 \\
4\end{array}$ & 0,001 & 0 & 0,07683 \\
\hline Lolium temulentumL. & 0,326 & $\begin{array}{l}0,15 \\
6\end{array}$ & 0,015 & $\begin{array}{l}0,00 \\
3\end{array}$ & 0,029 & 0 & 0,08816 \\
\hline Phalaris canariensisL. & 0,495 & $\begin{array}{l}0,11 \\
0\end{array}$ & 0,001 & $\begin{array}{l}0,01 \\
3\end{array}$ & 0,024 & 0 & 0,10716 \\
\hline $\begin{array}{l}\text { Pharagmites australis } \\
\text { (Cav.) Trın. ExSteudel }\end{array}$ & 0,317 & $\begin{array}{l}0,06 \\
4 \\
\end{array}$ & 0,010 & $\begin{array}{l}0,01 \\
9\end{array}$ & 0,001 & 0,057 & 0,078 \\
\hline Poa trivialisL. & 0,426 & $\begin{array}{l}0,02 \\
5\end{array}$ & 0,001 & $\begin{array}{l}0,00 \\
2\end{array}$ & 0,002 & 0 & 0,076 \\
\hline $\begin{array}{lll}\text { Setaria } \operatorname{glauca}(\mathrm{L} .) \quad \mathrm{P} . \\
\text { Beauv. } & & \\
\end{array}$ & 0,568 & $\begin{array}{l}0,11 \\
6\end{array}$ & 0,021 & $\begin{array}{l}0,03 \\
8\end{array}$ & 0,024 & 0 & 0,12783 \\
\hline $\begin{array}{l}\text { Setaria viridis (L.) P. } \\
\text { Beauv. }\end{array}$ & 11,583 & $\begin{array}{l}9,12 \\
0\end{array}$ & 10,725 & $\begin{array}{l}11,1 \\
20\end{array}$ & $\begin{array}{l}10,47 \\
5\end{array}$ & 10,125 & 10,5246 \\
\hline $\begin{array}{l}\text { Sorghum halepense(L.) } \\
\text { Pers. }\end{array}$ & 9,482 & $\begin{array}{l}5,10 \\
6\end{array}$ & 6,830 & $\begin{array}{l}8,10 \\
0\end{array}$ & 5,830 & 4,310 & 6,60966 \\
\hline \multicolumn{8}{|l|}{ DICOTYLEDONEAE } \\
\hline \multicolumn{8}{|l|}{$\begin{array}{l}\text { Familya:Amaranthace } \\
\text { ae }\end{array}$} \\
\hline $\begin{array}{l}\text { Amaranthus } \\
\text { blitoidesS.Wats. }\end{array}$ & 0,712 & $\begin{array}{l}0,01 \\
5 \\
\end{array}$ & 0,002 & $\begin{array}{l}0,02 \\
6 \\
\end{array}$ & 0,018 & $\begin{array}{r}-0,0 \\
\quad 73 \\
\end{array}$ & 0,141 \\
\hline $\begin{array}{l}\text { Amaranthus retroflexus } \\
\text { L. }\end{array}$ & 3,314 & $\begin{array}{l}1,10 \\
0\end{array}$ & 2,100 & $\begin{array}{l}1,11 \\
0 \\
\end{array}$ & 2,116 & 1,070 & 1,80166 \\
\hline \multicolumn{8}{|l|}{$\begin{array}{l}\text { Familya: Apiaceae } \\
\text { (Umbelliferae) }\end{array}$} \\
\hline Caucalis platycarposL. & 0,611 & 0 & 0 & 0 & 0 & 0 & 0,10183 \\
\hline Daucus carota $\mathrm{L}$. & 0,214 & $\begin{array}{l}0,01 \\
8 \\
\end{array}$ & 0 & $\begin{array}{l}0,01 \\
9 \\
\end{array}$ & 0 & 0 & 0,04183 \\
\hline \multicolumn{8}{|l|}{ Familya:Boraginaceae } \\
\hline Anchusa officinalisL. & 0,315 & 0 & 0,071 & 0 & 0 & 0 & 0,06433 \\
\hline $\begin{array}{l}\text { Heliotropium europaeum } \\
\text { L. }\end{array}$ & 0,627 & $\begin{array}{l}0,12 \\
9\end{array}$ & 0,002 & $\begin{array}{l}0,05 \\
1 \\
\end{array}$ & 0,003 & 0 & 0,13533 \\
\hline \multicolumn{8}{|l|}{$\begin{array}{l}\text { Familya:Caryophyllace } \\
\text { ae }\end{array}$} \\
\hline Agrostemma githago L. & 0,218 & 0 & 0 & 0 & 0 & 0 & 0,03633 \\
\hline $\begin{array}{l}\text { Vaccaria } \\
\text { pyramidataMedik. }\end{array}$ & 0,352 & $\begin{array}{l}0,01 \\
0 \\
\end{array}$ & 0 & $\begin{array}{l}0,02 \\
5 \\
\end{array}$ & 0 & 0 & 0,0645 \\
\hline Familya:Chenopodiace & & & & & & & \\
\hline
\end{tabular}




\begin{tabular}{|c|c|c|c|c|c|c|c|}
\hline $\mathbf{a e}$ & & & & & & & \\
\hline Chenopodium album $\mathrm{L}$. & 2,925 & $\begin{array}{l}1,22 \\
4\end{array}$ & 1,862 & $\begin{array}{l}0,32 \\
4\end{array}$ & 1,786 & 1,826 & 1,65783 \\
\hline Chenopodium vulvariaL. & 0,516 & 0 & 0 & 0 & & 0,063 & 0,1158 \\
\hline \multicolumn{8}{|l|}{$\begin{array}{l}\text { Familya:Compositae } \\
\text { (Asteraceae) }\end{array}$} \\
\hline $\begin{array}{l}\text { Acroptilon repens (L.) } \\
\text { DC. }\end{array}$ & 0,538 & $\begin{array}{l}0,11 \\
4 \\
\end{array}$ & 0 & 0 & 0 & 0 & 0,108667 \\
\hline Carduus nutansL. & 0,046 & 0 & 0 & 0 & 0 & 0 & 0,007667 \\
\hline $\begin{array}{l}\text { Centaurea solstitialis } \\
\text { subsp. solstitialis }\end{array}$ & 0,083 & $\begin{array}{l}0,01 \\
2 \\
\end{array}$ & 0 & $\begin{array}{l}0,01 \\
8 \\
\end{array}$ & 0 & 0,074 & 0,031167 \\
\hline Centaurea virgata Lam. & 0,041 & 0 & 0 & 0 & 0 & 0 & 0,006833 \\
\hline Chondrilla junceaL. & 0,034 & 0 & 0 & 0 & 0 & 0 & 0,005667 \\
\hline Cichorium intybusL. & 0,027 & 0 & 0 & 0 & 0 & 0 & 0,0045 \\
\hline $\begin{array}{l}\text { Cirsium arvense (L.) } \\
\text { Scop. }\end{array}$ & 0,098 & $\begin{array}{l}0,01 \\
3 \\
\end{array}$ & 0,012 & $\begin{array}{l}0,01 \\
1 \\
\end{array}$ & 0,003 & 0,082 & 0,0365 \\
\hline Lactuca serriola $\mathrm{L}$. & 3,568 & $\begin{array}{l}2,14 \\
7 \\
\end{array}$ & 3,620 & $\begin{array}{l}2,47 \\
0\end{array}$ & 1,162 & 3,240 & 2,701167 \\
\hline $\begin{array}{l}\text { Conyza canadensis }(\mathrm{L} .) \\
\text { Crom. }\end{array}$ & 0,056 & 0 & 0,001 & $\begin{array}{l}0,02 \\
6 \\
\end{array}$ & 0,032 & 0,095 & 0,035 \\
\hline MatricariachamomillaL. & 0,480 & $\begin{array}{l}0,12 \\
5 \\
\end{array}$ & 0,253 & $\begin{array}{l}0,21 \\
8 \\
\end{array}$ & 0,053 & 0,357 & 0,247667 \\
\hline Senecio vulgarisL. & 0,532 & 0 & 0 & 0 & 0 & 0 & 0,088667 \\
\hline Sonchus asper (L.) Hill. & 0,167 & $\begin{array}{l}0,00 \\
1 \\
\end{array}$ & 0,035 & $\begin{array}{l}0,01 \\
4 \\
\end{array}$ & 0,002 & 0,063 & 0,047 \\
\hline Sonchus oleraceusL. & 0,120 & $\begin{array}{l}0,02 \\
1 \\
\end{array}$ & 0,027 & $\begin{array}{l}0,01 \\
3\end{array}$ & 0,014 & 0,054 & 0,0415 \\
\hline Taraxacum aleppicum & 0,083 & 0 & 0 & 0 & 0 & 0 & 0,013833 \\
\hline $\begin{array}{l}\text { Taraxacum } \\
\text { officinaleF.H.Wigg. }\end{array}$ & 11,205 & $\begin{array}{l}9,15 \\
5\end{array}$ & 11,547 & $\begin{array}{l}5,15 \\
9\end{array}$ & $\begin{array}{l}12,32 \\
0\end{array}$ & 11,159 & 10,09083 \\
\hline XanthiumstrumariumL. & 1,150 & $\begin{array}{l}1,09 \\
0\end{array}$ & 1,140 & $\begin{array}{l}0,27 \\
8\end{array}$ & 1,243 & 1,040 & 0,990167 \\
\hline Xanthium spinosumL. & 0.459 & $\begin{array}{l}0,02 \\
6 \\
\end{array}$ & 0 & $\begin{array}{l}0,00 \\
2\end{array}$ & 0,006 & 0,014 & 0,0096 \\
\hline \multicolumn{8}{|l|}{$\begin{array}{l}\text { Familya: } \\
\text { Convolvulaceae }\end{array}$} \\
\hline Convolvulus arvensis $\mathrm{L}$. & 2,836 & $\begin{array}{l}0,13 \\
0\end{array}$ & 0,435 & $\begin{array}{l}1,31 \\
0\end{array}$ & 1,435 & 1,543 & 0,9706 \\
\hline Convolvulus sepium & 1,294 & 0 & 0 & 0 & 0 & 0,068 & 0,0136 \\
\hline \multicolumn{8}{|l|}{$\begin{array}{l}\text { Familya:Cruciferae }(\mathrm{Br} \\
\text { assicaceae })\end{array}$} \\
\hline Brassica nigra (L.) Koch & 0,145 & 0 & 0 & 0 & 0 & 0 & 0,024167 \\
\hline
\end{tabular}




\begin{tabular}{|c|c|c|c|c|c|c|c|}
\hline $\begin{array}{l}\text { Capsella bursa-pastoris } \\
\text { (L.) Medik. }\end{array}$ & 0,492 & $\begin{array}{l}0,02 \\
8\end{array}$ & 0,001 & $\begin{array}{l}0,01 \\
3\end{array}$ & 0,007 & 0,079 & 0,103333 \\
\hline $\begin{array}{l}\text { C. draba ssp draba (L.) } \\
\text { Desv. }\end{array}$ & 0,527 & $\begin{array}{l}0,01 \\
2 \\
\end{array}$ & 0,012 & $\begin{array}{l}0,01 \\
1 \\
\end{array}$ & 0,005 & 0,061 & 0,104667 \\
\hline Sinapis arvensis $\mathrm{L}$. & 0,321 & $\begin{array}{l}0,02 \\
7\end{array}$ & 0,056 & $\begin{array}{l}0,00 \\
3\end{array}$ & 0,009 & 0,059 & 0,079167 \\
\hline \multicolumn{8}{|l|}{ Familya: Cuscutaceae } \\
\hline $\begin{array}{l}\text { Cuscuta } \\
\text { campestrisYuncker }\end{array}$ & 0,814 & 0 & 0 & 0 & 0,023 & 0,042 & 0,1465 \\
\hline \multicolumn{8}{|l|}{$\begin{array}{l}\text { Familya: } \\
\text { Euphorbiaceae }\end{array}$} \\
\hline $\begin{array}{l}\text { Euphorbia helioscopia } \\
\text { L. }\end{array}$ & 0,135 & 0 & 0 & 0 & 0 & 0 & 0,0225 \\
\hline Euphorbia orientalis L. & 0,782 & $\begin{array}{l}0,05 \\
6 \\
\end{array}$ & 0,068 & $\begin{array}{l}0,00 \\
3\end{array}$ & 0,005 & 0,063 & 0,162833 \\
\hline Euphorbia prostrata & 0,328 & $\begin{array}{l}0,05 \\
0 \\
\end{array}$ & 0,031 & $\begin{array}{l}0,03 \\
6\end{array}$ & 0,067 & 0,094 & 0,101 \\
\hline \multicolumn{8}{|l|}{$\begin{array}{l}\text { Familya: Fabaceae } \\
\text { (Leguminosae) }\end{array}$} \\
\hline $\begin{array}{l}\text { Medicago minima }(\mathrm{L} .) \\
\text { Bart. }\end{array}$ & 0,047 & 0 & 0,001 & $\begin{array}{l}0,04 \\
2\end{array}$ & 0,002 & 0,015 & 0,017833 \\
\hline $\begin{array}{l}\text { Medicago rigidula (L.) } \\
\text { All.. }\end{array}$ & 0,026 & $\begin{array}{l}0,01 \\
0\end{array}$ & 0,002 & 0 & 0 & 0 & 0,006333 \\
\hline Medicago sativa $\mathrm{L}$. & 0,451 & $\begin{array}{l}0,01 \\
8 \\
\end{array}$ & 0,043 & $\begin{array}{l}0,08 \\
7\end{array}$ & 0,063 & 0,086 & 0,124667 \\
\hline $\begin{array}{l}\text { Medicago } \\
\text { truncatulaGaertn. }\end{array}$ & 0,123 & $\begin{array}{l}0,02 \\
7 \\
\end{array}$ & 0 & 0 & 0 & 0 & 0,025 \\
\hline $\begin{array}{l}\text { Melilotus officinalis(L.) } \\
\text { Desr. }\end{array}$ & 0,248 & $\begin{array}{l}0,09 \\
2\end{array}$ & 0,002 & $\begin{array}{l}0,04 \\
1\end{array}$ & 0,082 & 0 & 0,0775 \\
\hline $\begin{array}{l}\text { Lotus corniculatusL. var. } \\
\text { corniculatus }\end{array}$ & 0,136 & 0 & 0 & 0 & 0 & 0 & 0,022667 \\
\hline $\begin{array}{l}\text { Prosopis farcta(Banks et } \\
\text { Sol.) Mac. }\end{array}$ & 0,074 & $\begin{array}{l}0,06 \\
2\end{array}$ & 0,031 & $\begin{array}{l}0,08 \\
3\end{array}$ & 0,094 & 0,051 & 0,065833 \\
\hline $\begin{array}{l}\text { Trifolium } \\
\text { campestreSchreb. }\end{array}$ & 0,569 & $\begin{array}{l}0,04 \\
5 \\
\end{array}$ & 0,112 & $\begin{array}{l}0,07 \\
2\end{array}$ & 0,051 & 0,073 & 0,153667 \\
\hline Trifolium fragiferumL. & 0,218 & $\begin{array}{l}0,04 \\
1\end{array}$ & 0,145 & 0 & 0 & 0 & 0,067333 \\
\hline Trifolium pratense $\mathrm{L}$. & 0,785 & $\begin{array}{l}0,37 \\
9\end{array}$ & 0,096 & $\begin{array}{l}0,08 \\
6\end{array}$ & 0,085 & 0,647 & 0,346333 \\
\hline Trifolium repensL. & 0,864 & $\begin{array}{l}0,27 \\
4\end{array}$ & 0,210 & $\begin{array}{l}0,19 \\
2\end{array}$ & 0,612 & 0,711 & 0,477167 \\
\hline Vicia sativa $\mathrm{L}$. & 0,269 & 0,01 & 0 & 0 & 0,074 & 0 & 0,060167 \\
\hline
\end{tabular}




\begin{tabular}{|c|c|c|c|c|c|c|c|}
\hline & & 8 & & & & & \\
\hline Vicia craccaL. & 0,170 & $\begin{array}{l}0,02 \\
1 \\
\end{array}$ & 0 & $\begin{array}{l}0,00 \\
4\end{array}$ & 0,005 & 0,006 & 0,034333 \\
\hline \multicolumn{8}{|l|}{ Familya: Geraniaceae } \\
\hline $\begin{array}{l}\text { Erodium cicutarium }(\mathrm{L} .) \\
\text { Lâ'Herit. }\end{array}$ & 0,052 & 0 & 0 & 0 & 0 & 0 & 0,008667 \\
\hline Geranium lucidumL. & 0,081 & 0 & 0 & 0 & 0 & 0 & 0,0135 \\
\hline \multicolumn{8}{|l|}{$\begin{array}{l}\text { Familya: Hypericaceae } \\
\text { (Guttiferae) }\end{array}$} \\
\hline Hypericum perforatum & 0,013 & 0 & 0 & 0 & 0 & 0 & 0,002167 \\
\hline \multicolumn{8}{|l|}{$\begin{array}{ll}\text { Familya: } & \text { Labiatae } \\
\text { (Lamiaceae) } & \\
\end{array}$} \\
\hline Lamium amplexicaule $\mathrm{L}$. & 0,025 & 0 & 0 & $\begin{array}{l}0,00 \\
4 \\
\end{array}$ & 0,053 & 0,006 & 0,014667 \\
\hline $\begin{array}{l}\text { Mentha longifolia }(\mathrm{L} .) \\
\text { Hudson }\end{array}$ & 0,081 & 0 & 0 & $\begin{array}{l}0,03 \\
5 \\
\end{array}$ & 0 & 0 & 0,019333 \\
\hline \multicolumn{8}{|l|}{ Familya: Malvaceae } \\
\hline Malva neglectaWallr. & 3,475 & $\begin{array}{l}1,15 \\
9 \\
\end{array}$ & 2,745 & $\begin{array}{l}1,59 \\
6 \\
\end{array}$ & 2,375 & 2,415 & 2,294167 \\
\hline Malva sylvestrisL. & 0,852 & $\begin{array}{l}0,04 \\
5\end{array}$ & 0,005 & 0 & 0,024 & 0,007 & 0,1555 \\
\hline Hibiscus trionum & 0,096 & $\begin{array}{l}0,00 \\
1\end{array}$ & 0,032 & 0 & 0,012 & 0,053 & 0,032333 \\
\hline \multicolumn{8}{|l|}{ Familya: Oxalidaceae } \\
\hline Oxalis corniculata $\mathrm{L}$. & 0,042 & $\begin{array}{l}0,00 \\
5\end{array}$ & 0 & 0 & 0,013 & 0,004 & 0,010667 \\
\hline \multicolumn{8}{|l|}{ Familya: Papaveraceae } \\
\hline Fumaria officinalis L. & 0,128 & $\begin{array}{l}0,04 \\
2 \\
\end{array}$ & 0 & 0 & 0 & 0 & 0,028333 \\
\hline Papaver dubium & 0,463 & $\begin{array}{l}0,14 \\
8\end{array}$ & 0 & 0 & 0 & 0 & 0,101833 \\
\hline Papaver hybridum & 0,319 & $\begin{array}{l}0,21 \\
3\end{array}$ & 0 & 0 & 0 & 0,032 & 0,094 \\
\hline Papaver rhoeas L. & 0,680 & $\begin{array}{l}0,35 \\
9\end{array}$ & 0,437 & $\begin{array}{l}0,72 \\
5\end{array}$ & 0,613 & 0,836 & 0,608333 \\
\hline \multicolumn{8}{|l|}{$\begin{array}{l}\text { Familya: } \\
\text { Plantaginaceae }\end{array}$} \\
\hline Plantago lanceolata $\mathrm{L}$. & 0,216 & $\begin{array}{l}0,04 \\
1 \\
\end{array}$ & 0,081 & $\begin{array}{l}0,06 \\
2 \\
\end{array}$ & 0,034 & 0,009 & 0,073833 \\
\hline Plantago majör $\mathrm{L}$. & 0,230 & $\begin{array}{l}0,01 \\
2\end{array}$ & 0,001 & 0 & 0,061 & 0,074 & 0,063 \\
\hline
\end{tabular}




\begin{tabular}{|c|c|c|c|c|c|c|c|}
\hline \multicolumn{8}{|l|}{ Familya: Polygonaceae } \\
\hline Polygonum aviculare $\mathrm{L}$. & 0,114 & $\begin{array}{l}0,00 \\
2\end{array}$ & 0 & 0 & 0 & 0,043 & 0,0265 \\
\hline $\begin{array}{l}\text { Polygonum convolvulus } \\
\text { L. }\end{array}$ & 0,169 & $\begin{array}{l}0,00 \\
3\end{array}$ & 0 & 0 & 0,005 & 0,027 & 0,034 \\
\hline Polygonu mpersicaria L. & 0,142 & $\begin{array}{l}0,00 \\
1 \\
\end{array}$ & 0 & 0 & 0,004 & 0,006 & 0,0255 \\
\hline Rumex crispusL. & 7,351 & $\begin{array}{l}3,34 \\
2 \\
\end{array}$ & 6,154 & $\begin{array}{l}4,34 \\
6 \\
\end{array}$ & 5,856 & 6,534 & 5,597167 \\
\hline Rumex tuberosus L. & 0,130 & $\begin{array}{l}0,00 \\
4 \\
\end{array}$ & 0,001 & 0 & 0 & 0,006 & 0,0235 \\
\hline \multicolumn{8}{|l|}{ Familya: Portulacaceae } \\
\hline Portulaca oleraceaL. & 11,084 & $\begin{array}{l}9,18 \\
7\end{array}$ & 10,184 & $\begin{array}{l}5,18 \\
7 \\
\end{array}$ & 8,283 & 10,184 & 9,018167 \\
\hline \multicolumn{8}{|l|}{ Familya: Primulaceae } \\
\hline Anagallis arvensis $\mathrm{L}$. & 0,100 & 0 & 0 & 0 & 0 & 0 & 0,016667 \\
\hline \multicolumn{8}{|l|}{$\begin{array}{l}\text { Familya: } \\
\text { Ranunculaceae }\end{array}$} \\
\hline Adonis flammea Jacq. & 0,125 & $\begin{array}{l}0,11 \\
3\end{array}$ & 0 & $\begin{array}{l}0,00 \\
3\end{array}$ & 0 & 0 & 0,040167 \\
\hline Ranunculus millefoliusL. & 0,092 & 0 & 0 & 0 & 0 & 0 & 0,015333 \\
\hline Ranunculus arvensisL. & 0,065 & 0 & 0,001 & $\begin{array}{l}0,00 \\
2\end{array}$ & 0,003 & 0,005 & 0,012667 \\
\hline \multicolumn{8}{|l|}{ Familya:Rosaceae } \\
\hline Rosa montanaChaix. & 0,002 & 0 & 0 & 0 & 0 & 0,009 & 0,001833 \\
\hline Rubus canescens D.C. & 0,001 & 0 & 0 & 0 & 0 & 0,007 & 0,001333 \\
\hline \multicolumn{8}{|l|}{ Familya: Rubiaceae } \\
\hline Galium aparineL. & 0,074 & 0 & 0 & $\begin{array}{l}0,00 \\
2\end{array}$ & 0,004 & 0,003 & 0,013833 \\
\hline \multicolumn{8}{|l|}{$\begin{array}{l}\text { Familya: } \\
\text { Scrophulariaceae } \\
\text { (Scrophyllaceae) }\end{array}$} \\
\hline $\begin{array}{l}\text { Verbascum } \\
\text { lasianthumBoiss.Ex. } \\
\text { Bent. }\end{array}$ & 0,012 & 0 & 0 & 0 & 0,001 & 0,007 & 0,003333 \\
\hline \multicolumn{8}{|l|}{ Familya: Solanacea } \\
\hline Solanum nigrumL. & 3,482 & $\begin{array}{l}0,11 \\
4\end{array}$ & 2,183 & $\begin{array}{l}1,14 \\
8\end{array}$ & 1,185 & 2,384 & 1,749333 \\
\hline \multicolumn{8}{|l|}{ Familya: Urticaceae } \\
\hline Urtica urens $\mathrm{L}$. & 0,326 & $\begin{array}{l}0,00 \\
1 \\
\end{array}$ & 0,002 & $\begin{array}{l}0,00 \\
1 \\
\end{array}$ & 0,002 & 0,005 & 0,056167 \\
\hline Familya:Zygophyhllace & & & & & & & \\
\hline
\end{tabular}




\begin{tabular}{|c|l|l|l|l|l|l|l|}
\hline ae & & & & & & & \\
\hline Tribulus terrestrisL. & 0,518 & 0,00 & 0,003 & 0,00 & 0,007 & 0,006 & \\
& & 2 & & 2 & 0,089667 \\
\hline Total density & $\mathbf{1 6 5 , 3 9}$ & $\begin{array}{l}\mathbf{9 8 , 1} \\
\mathbf{9 9}\end{array}$ & $\begin{array}{l}\mathbf{1 1 4 , 1 5} \\
\mathbf{9}\end{array}$ & $\begin{array}{l}\mathbf{9 9 , 8} \\
\mathbf{9 6}\end{array}$ & $\begin{array}{l}\mathbf{1 1 3 , 0} \\
\mathbf{3 0}\end{array}$ & $\mathbf{1 0 6 , 1 6 4}$ & $\mathbf{1 1 6 , 1 3 9 7}$ \\
\hline
\end{tabular}

The maximum frequency occurrence for weed species was; $52.7 \%$ for A. repens, $52.3 \%$ for $T$. officinale, $52.1 \%$ for P. oleracea, $51.9 \%$ for S. viridis, $51.6 \%$ for C. dactylon and $50.8 \%$ for D. sanguinalis.

General coverage of weeds were $34.2 \%$ for $T$. officinale, $33.5 \%$ for P. oleracea, $32.1 \%$ for $A$. repens, $30.4 \%$ for $C$. dactylon, $29.8 \%$ for $D$. sanguinalis and $27.1 \%$ for S. viridis respectively.

In this study, weed species have been identified that with shows great similarities with Tastan and Ercis [4], Sözeri et al., [7], Ulug et al., [17], Kitis, [10], Güncan and Karaca [11], Güncan [2]. But Weed frequency of occurence, general coverage, the type and intensity may varies depending from region to region, ecological characteristics, soil structure, the types of crops grown and altitude.

\section{Recommendations}

The soil to be used for ornamental plant growth should be treated with pre-sowing or preplanting herbicides. The herbicides should not be used only in the area of planting. The spaces between parcells must also be treated. Sowing and planting date must be determined by considering the effective duration of the herbicide used. Other control methods with weeds;

\subsection{Weeds control methods}

Weeds have the capability of germinating earlier compared to ornamental plants. Their riding lawn capacity is quite high as well. The harm of the weeds on ornamental plants can be classified into two types; primary and secondary. Primary harm is that weeds, thanks to their strong root system and the ability to grow fast, use the nutritions (nitrogen, phosphor, potasium, iron zinc, etc.) and water required for the growth of ornamentals and grass. They may even consume 3 to four times more of them compared to landscaping plants. Secondary harm is done by blocking humidity and the light needed by ornamentals because of the fact that weeds' above-soil section grow too fast (vegatatively). 


\subsection{Cultural control method Protective precautions}

In order to prevent weeds from becoming a problem for ornamentals and the lawns, first thing to do is to check the weeds in the area to be used for constitution. To achieve this, the soil in the area must be processed superficially 45 days prior to the planting. 10 days after the process, growing weeds will be observed. Before the weeds bloom, the soil will be processed again, and the seeds that were dormant in the soil thus will germinate. After the tilth, a decrease in the population of weeds will decrease. With the soil processing to be performed during the planting, the amount of the weed existing as reserved in the soil will be lowered more, and the carbohydrate reserves in the storage organs of prenneial plants will also be reduced. Additionally, preparing the seed bed properly is crucial for all the seeds to germinate monotonously and that there would be no space between them. Otherwise, the weed would grow in the empty spaces. Drainage of the land must also be done. during or before the planting, the animal manure to be used must be fermented effectively. If not, the alive seeds in the fertilizer can germinate and spread. For these reasons, the maintenance of the ornamental and the lawns must be performed with great care. Of all these steps, watering, fertilizing and mowing are the most improtant ones.

\subsection{Mowing method}

One of the most important maintenance processes is mowing. The frequency and the height of mowing varies depending on the area in which the grass is used, the season and the mixture applied. Through this fighting method, tall and prenneial weed species for the ornamentals formed as trees, and bushes for the lawns, are tried to be eliminated by mowing them during the time of blossom.

\subsection{Plucking by hand method}

It is a fighting method based on plucking the weeds around the ornamentals or in the lawns by using hands and/or certain tools.

\subsection{Mechanical control method Soil processing}

This method is inexpensive and effective. It is mostly used for the fight against annual weeds.

\subsection{Hoeing}

In the cultivation of tupil, clove and gladiola, hoeing is crucial. It is generally applied when the weeds at the stage with 8 to 10 leaves. 


\subsection{Chemical control method}

We try to fight against the weeds we could not eliminate through cultural and mechanical methods by chemical (herbicide) fighting. The first step in this method is to treat the soil with tootal herbicide before the seeds of the ornamentals are sewed or the cuts are planted. Sewing and planting time must be determined by considering how long the herbicides remain effective. Attention must be paid to that the herbicides treatment must be performed before sewing and planting. In case of being obligated to use after sewing or planting, it must be remembered that most herbicides show a phytotoxic effect on these plants.

It is a method that is commonly used in the lawns in recent years. The chemicals used in this method are separated into two groups according to the way they affect the weeds as contact and systemic effect. They cause the weeds die by cloking the phosynthesis, nucleic acid or protein synthesis in them. Nearly 1 to 7 days after treatment, the weeds begin to die off gladiola [21].

\section{References}

1. Anonymous, (2015). Crop production statistics.www.tuik.gov.tr

2. Güncan, A. (2016). Weeds and control principles. Selcuk University printing office Textbook, Page, 311. Konya. Turkey.

3. Batman, M., (1987). The control of weeds in grass in Ankara'. Ankara University, Institute of Natural and Applied Sciences, Plant Protection Department (Unpublished), Ankara. Turkey.

4. Tastan, B. and Ercis, A. (1989). Investigations on the challenges chemical Weed species and densities in.Ankara Province. KKGA-B-01-H-082 number project. Final report. Ankara Agricultural Struggle Research institute, Ankara. Turkey.

5. Tastan, B. and Ercis, A. (1993). Weed species their abundances and chemical control in lawns in Ankara province. Turkish Journal of Agriculture and Forestry, 17(2), P. 331-337. 
6. Grant, D.L., Cooper, R.B. and Webster, H.L. (1990). Isoxaben for Brood-spectrum weed control in warm season Turf. In proceedings, Southern Weed Science Society, 43.nd Annual meeting, 145-153. (Weed Abstr. 1991, 40 (4), 1083).

7. Sözer, S. Maden, S., Yazgan, M.E., Açıksöz, S., Kendir, H., Dılek, E.F. and Karadeniz, N. (1998). A Research on the Weed Control Possibilities During Establishment Stages of Lawn Areas as a Maintenance Tool Under Central Anatolian Conditions. Journal of Agricultural Sciences.1998, 4 (2), P. 8-14.

8. Altınısık, N. and Kadıoğlu, İ. (2003). Study on the determination of weed species and their control measures in the turfgrassareas of Sabiha Gokcen. . University of Gazı Osman Pasa, Journal of Africulture Faculty, 20 (2), P.1-8.

9. Anonymous, (2007). Landscape gardening. www.konya.bel.tr/images/parkbahceler/pdf/bahce_duzenleme_peyzaj.pdf

10. Kitiş, Y.E. (2011). Weed Control in Lawns. Agriculture Journal Magazine, 2, P. 18-22.

11. Güncan, A.and Karaca, M. (2014). Weeds and control principles. Selcuk University Printing office Textbook, Konya, Turkey.

12. Anonymous, (2015a) Lawn area installation and maintenance.www.anadoluparkbahceler.com/pdf/cim-alan-tesisi-ve-bakimi.pdf

13. Odum,E.P. (1971).Fundamentals of Ecology.W.B.Saunders Company, Philadelphia, London,Toronto, $574 \mathrm{pp}$.

14. Uygur, F.N., Kadığlu, İ., and Boz, Ö. (1993). First Herbology Congress of Turkey.3-5 February 1993-Adana, P. 87-91.

15. Güncan, A. (2001). Weeds and Principles, Selçuk University, Agriculture faculty, Textbook., Konya. Turkey.

16. Baytop, A. (1985). Flora Of Turkey and the East Aegean Islands., Vol. 9:724.,

17. Uluğ, E., Kadığlu, İ. and Üremiş, İ. (1993). Turkey's weeds and some characteristics, Agriculture and Village Affairs Ministry, Agricultural Struggle Research institute. Publication number: 78, P. 513, Adana. Turkey.

18. Altınayar, G. (1988). Water weeds. T.C. Ministry of Public Works and Settlement, General Directorate of State Hydraulic Works, Directorate of Operation and Maintenance Department, Ankara/Turkey, P.231.

19. Davis, P.H. (1965-1988). Flora of Turkey and East Aegean 1slands. University Press Edinburg. Cilt1-10.

20. Üstüner, T. and Güncan, A. (2002). Researches on weed species which are problem density and importance with association in potato fileds of Niğde province. Turkey herbology journal, Volume;5, number;2, page;30-41. 
Middle East J. of Science (2017) 3(1):32-50

21. Anonim, (2015b). Licensed Plant Protection Products. Ministry of Agriculture and Rural Affairs, General Directorate of Protection and Control publications, Ankara, Turkey. 